$\begin{array}{cc}\text { ACADEMIA ROMÂNĂ } & \text { Rev. Roum. Chim., } \\ \text { 2019, 64(10), 887-892 }\end{array}$

\title{
PHTHALOCYANINE MODIFIED ELECTRODES BASED ON REDUCED GRAPHENE OXIDE FOR DETERMINATION OF LEAD IN DIFFERENT TYPES OF WATER
}

\author{
Georgiana-Luiza ARNOLD TATU and Jacobus Frederick VAN STADEN* \\ Laboratory of Electrochemistry and PATLAB Bucharest, \\ National Institute of Research for Electrochemistry and Condensed Matter, Bucharest 060021, Romania
}

Received October 5, 2018

In this study, modified electrodes based on reduced graphene oxide modified with iron (II) phthalocyanine or nickel (II) phthalocyanine were used for determination of lead in different types of water samples using differential pulse anodic stripping voltammetry. The lowest limits of quantification obtained, were $0.001035 \mu \mathrm{g} \mathrm{L}^{-1}$ for the modified electrodes, and $0.00207 \mu \mathrm{g} \mathrm{L}^{-1}$ for unmodified electrodes, with a correlation coefficient $\left(\mathrm{R}^{2}\right)$ between 0.996 and 0.997 . The results obtained for the different sensors on real water samples were compared with the standard ISO method (SR EN ISO 11885:2009) using inductively coupled plasma optical emission spectrometry (ICP-OES) and it can be seen that all the sensors compared very well for the determination of $\mathrm{Pb}^{2+}$ ions in different types of water.

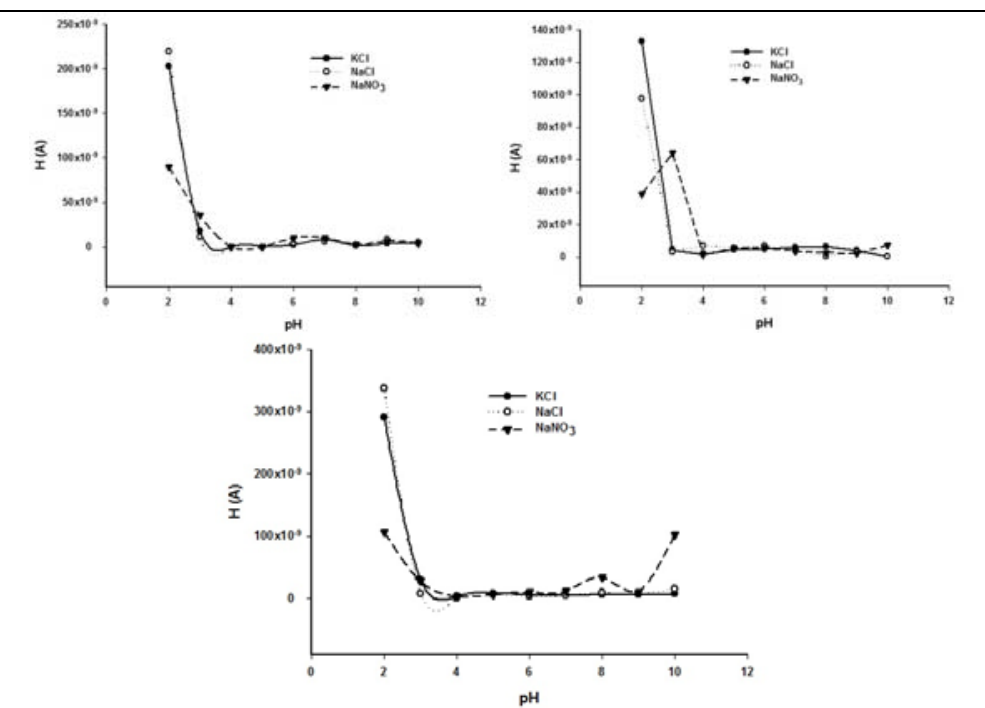

\section{INTRODUCTION}

There is currently a great concern in Europe (at the European Commission) about some "toxic" substances that are regularly detected in food coming from a number of food sources. ${ }^{1-4}$ Retrieval data studies revealed that the consumption of contaminated commodities is related to several acute chronic diseases in humans and animals. ${ }^{5-7}$

Lead from lead batteries, corrosion of lead (housing and other lead plumbing systems) from lead and iron pipes (example Flint river, USA), contamination of lead from the environment and leaching of lead from these sources into fresh water rivers and lakes (even into food commodities) can eventually become harmful to humans. ${ }^{8-15}$

A reliable, sustainable and convenient analytical method therefore becomes needed for the determination of lead ions in water. Lead concentrations in drinking water should be below the EPA action level of $0.015 \mathrm{mg} \mathrm{L}^{-1}$ (parts per billion). ${ }^{16,17}$

We, therefore, developed a simple, sensitive and selective electrochemical method for the determination of lead ions in water. The method is based on reduced graphene oxide modified

\footnotetext{
* Corresponding author: koosvanstaden2012@yahoo.com, koosvanstaden@patlab.ro
} 
electrodes with phthalocyanine for the detection of lead from different types of water samples (e.g., fresh water, underground water, geothermal waste water) using differential pulse anodic stripping voltammetry (DPASV). The results compared favourably with standard iso-certified methods.

\section{EXPERIMENTAL}

\section{Reagents and instrumentation}

All chemicals were of analytical reagent grade, and $\mathrm{Pb}\left(\mathrm{NO}_{3}\right)_{2}, \mathrm{KCl}, \mathrm{NaCl}, \mathrm{NaNO}_{3}, \mathrm{NaH}_{2} \mathrm{PO}_{4} \cdot \mathrm{H}_{2} \mathrm{O}, \mathrm{Na}_{2} \mathrm{HPO}_{4}$ for the different solutions were purchased from Sigma-Aldrich. Reduced graphene oxide (RGox) was supplied by Sigma Aldrich, and paraffin oil by Fluka (Buchs, Sweden). Iron(II) phthalocyanine (Fe(II)Pc) and nickel(II) phthalocyanine (Ni(II)Pc) were from Aldrich.

Phosphate buffer solutions (PBS, $0.1 \mathrm{~mol} \mathrm{~L}^{-1}$ ) with $\mathrm{pH}=2$ 10 were prepared by using different ratios between $\mathrm{NaH}_{2} \mathrm{PO}_{4}$ and $\mathrm{Na}_{2} \mathrm{HPO}_{4}$. Hydrogen chloride $\left(\mathrm{HCl}, 0.1 \mathrm{~mol} \mathrm{~L}^{-1}\right.$ ) and sodium hydroxide $\left(\mathrm{NaOH}, 0.1 \mathrm{~mol} \mathrm{~L}^{-1}\right)$ solutions were used for $\mathrm{pH}$ adjustment.

The standard solutions for differential pulse voltammetry (DPV) were prepared using $10^{-3} \mathrm{~mol} \mathrm{~L}^{-1}\left(207000 \mu \mathrm{g} \mathrm{L}^{-1}\right)$ of $\mathrm{Pb}^{2+}$ as stock solutions. All standard solutions of $\mathrm{Pb}^{2+}$ in the range $10^{-4}-10^{-12} \mathrm{~mol} \mathrm{~L}^{-1}\left(20700-0.000207 \mu \mathrm{g} \mathrm{L}^{-1}\right)$ were prepared from the stock solution by serial dilution, with phosphate buffer solution (PBS) of different pHs containing $\mathrm{KCl}, \mathrm{NaCl}$ or $\mathrm{NaNO}_{3}\left(0.1 \mathrm{~mol} \mathrm{~L}^{-1}\right)$ as supporting electrolytes.

All solutions were prepared using deionized water obtained from a Direct-Q 3 Water Purification system (Millipore Corporation, France).

All measurements were recorded using a PGSTAT 100 potentiostat/galvanostat connected to a three electrode cell, and linked to a computer via an Eco Chemie (Utretch, The Netherlands) software version 4.9. $\mathrm{An} \mathrm{Ag} / \mathrm{AgCl}$ electrode served as reference electrode and a platinum electrode served as auxiliary electrode, new developed sensors served as working electrodes in the electrochemical cell. The $\mathrm{pH}$ measurements were performed using a CyberScan PCD 6500 Multiparameter.

DPV curves have been recorded at $0.01 \mathrm{~V} \mathrm{~s}^{-1}$, with a pulse height of $0.025 \mathrm{~V}$ and step potential of $0.05 \mathrm{~V}$. All measurements were performed at $25^{\circ} \mathrm{C}$.

\section{Design of the microsensors RGox, Fe(II)Pc/RGox, Ni(II)Pc/RGox}

Reduced graphene oxide (RGox) pastes were modified with iron(II) phthalocyanine (Fe(II)Pc) or nickel(II) phthalocyanine $(\mathrm{Ni}(\mathrm{II}) \mathrm{Pc})$. The modified reduced graphene oxide pastes were prepared as follows: $100 \mathrm{mg}$ of reduced graphene oxide powder were mixed with $30 \mu \mathrm{L}$ paraffin oil to form the reduced graphene oxide pastes. $25 \mu \mathrm{L}$ from the solution of $\mathrm{Fe}(\mathrm{II}) \mathrm{Pc}\left(10^{-3} \mathrm{~mol} \mathrm{~L} \mathrm{~L}^{-1}\right.$, prepared in dimethyl sulfoxide) or $\mathrm{Ni}$ (II)Pc $\left(10^{-3} \mathrm{~mol} \mathrm{\textrm {L } ^ { - 1 }}\right.$, prepared in $\mathrm{N}, \mathrm{N}$ dimethylformamide) was added to the reduced graphene oxide pastes mixed with $25 \mu \mathrm{L}$ paraffin oil. The modified paste was placed into a very small plastic tube. Electrical contact was obtained with an $\mathrm{Ag}$ wire inserted into the paste. The surface of the electrode can be renewed by polishing with alumina paper. When not in use, the sensors were stored in a dry state, away from day light and at room temperature.

\section{RESULTS AND DISCUSSION}

\section{Optimization of working conditions}

Various DPV curves $\left(0.01 \mathrm{~V} \mathrm{~s}^{-1}\right)$ were recorded in order to optimized the working conditions for RGox, Fe(II)Pc/RGox, Ni(II)Pc/RGox sensors, using a $10^{-6} \mathrm{~mol} \mathrm{~L}^{-1}\left(207 \mu \mathrm{g} \mathrm{L}^{-1}\right)$ solution of $\mathrm{Pb}^{2+}$ ions. Three different supporting electrolytes were tested $\left(0.1 \mathrm{~mol} \mathrm{~L}^{-1} \mathrm{NaCl}, 0.1 \mathrm{~mol} \mathrm{~L}^{-1} \mathrm{KCl}\right.$ and $0.1 \mathrm{~mol} \mathrm{~L}^{-1} \mathrm{KNO}_{3}$ ) in PBS $\mathrm{pH}=2-10$. Figure 1 show the effect of $\mathrm{pH}$ and supporting electrolyte on the peak height for each sensor, using a solution of $10^{-6} \mathrm{~mol} \mathrm{~L}^{-1}\left(207 \mu \mathrm{g} \mathrm{L}^{-1}\right) \mathrm{Pb}^{2+}$ ions. The sensor sensitivity increases in lower $\mathrm{pH}$ solutions. The supporting electrolyte with $0.1 \mathrm{~mol} \mathrm{~L}^{-1} \mathrm{KCl}$, PBS $\mathrm{pH}=2$ gave the best results for the Fe(II)Pc/RGox sensor. For RGox and Ni(II)Pc/RGox sensors we observed that the following two supporting electrolytes have a good response: $0.1 \mathrm{~mol} \mathrm{~L}^{-1} \mathrm{KCl}$, PBS $\mathrm{pH}=2$ or $0.1 \mathrm{~mol} \mathrm{~L}^{-1} \mathrm{NaCl}$, PBS $\mathrm{pH}=2$.

\section{Optimization the parameters for the condition parameters}

Influence of various parameters deposition potential, deposition time for RGox, for $\mathrm{Fe}(\mathrm{II}) \mathrm{Pc} /$ RGox and for $\mathrm{Ni}(\mathrm{II}) \mathrm{Pc} / \mathrm{RGox}$ sensors were determinate using different supporting electrolytes in $10^{-6} \mathrm{~mol} \mathrm{~L}^{-1}\left(207 \mu \mathrm{g} \mathrm{L}^{-1}\right) \mathrm{Pb}^{2+}$ ions. Figure 2 shows the results for deposition potential and deposition time using different supporting electrolytes. RGox or Ni(II)Pc/RGox sensors used two supporting electrolytes: $0.1 \mathrm{~mol} \mathrm{~L}^{-1} \mathrm{KCl}$, PBS $\mathrm{pH}=2$ or $0.1 \mathrm{~mol} \mathrm{~L}^{-1} \mathrm{NaCl}$, PBS $\mathrm{pH}=2$. For $\mathrm{Fe}(\mathrm{II}) \mathrm{Pc} / \mathrm{RGox}$ sensor only one supporting electrolyte was used: $0.1 \mathrm{~mol} \mathrm{~L}^{-1} \mathrm{KCl}$, PBS $\mathrm{pH}=2$. For all sensors the optimal response was using $0.1 \mathrm{~mol} \mathrm{~L}^{-1} \mathrm{KCl}$, PBS $\mathrm{pH}=2$ as supporting electrolyte and with a deposition potential for $-1.2 \mathrm{~V}$ and with a deposition time of $150 \mathrm{~s}$. 


\section{Response characteristic for $\mathbf{P b}^{2+}$ ions}

The response characteristic for $\mathrm{Pb}^{2+}$ ions is presented in Table 1 and in Figure 3. All three sensors have the proper high correlation coefficients $\left(\mathrm{R}^{2}\right)$ above 0.997 . The highest sensitivity $\left(3.8 \times 10^{-7} \mathrm{~A} \mu \mathrm{g}\right.$ $\mathrm{L}^{-1}$ ) was obtained for the unmodified sensor with a

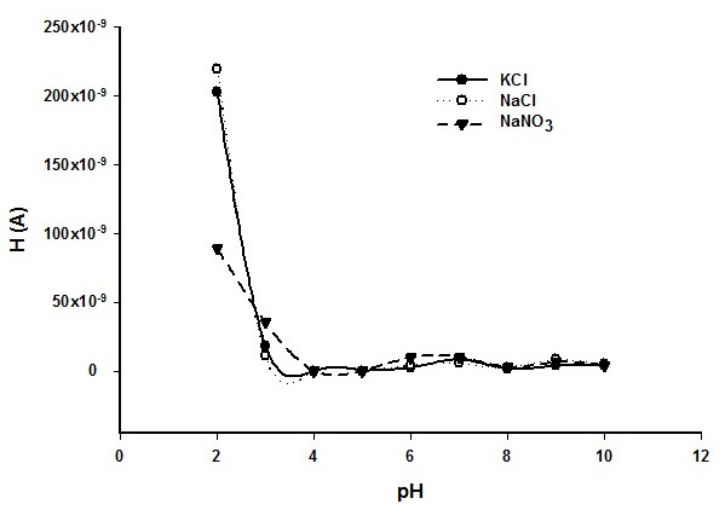

a

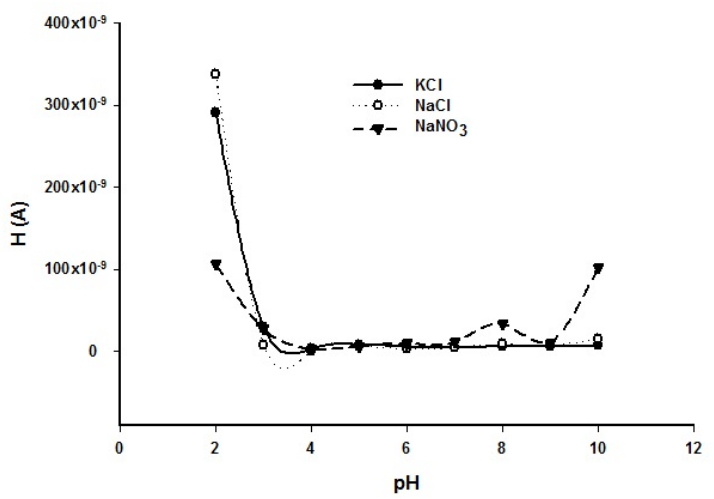

c

Fig. 1 - The effect of electrolyte and $\mathrm{pH}$ on the peak height for a concentration of $\mathrm{Pb}^{2+}$ solution of $10^{-6} \mathrm{~mol} \mathrm{~L}^{-1}\left(207 \mu \mathrm{g} \mathrm{L} \mathrm{L}^{-1}\right)$ : (a) RGox, (b) Fe(II)Pc/RGox, (c) Ni(II)Pc/RGox where $\mathrm{H}$ is the peak height (A).

Table 1

Response characteristics of the electrodes used for determination of $\mathrm{Pb}^{2+}$

\begin{tabular}{c|c|c|c|c|c}
\hline Parameter & $\begin{array}{c}\text { Equation of } \\
\text { calibration* }\end{array}$ & $\mathbf{r}$ & $\begin{array}{c}\text { Sensitivity } \\
\left(\mathbf{A} \boldsymbol{\mu g ~ \mathbf { L } ^ { - 1 }}\right)\end{array}$ & $\begin{array}{c}\text { Linear conc. } \\
\text { range }\left(\boldsymbol{\mu g} \mathbf{~ L}^{-1}\right)\end{array}$ & $\begin{array}{c}\text { Limit of } \\
\text { quantification } \\
\left(\boldsymbol{\mu g} \mathbf{L}^{-1}\right)\end{array}$ \\
\hline Sensors & $\mathrm{H}=2.3 \times 10^{-9}+3.8 \times 10^{-7} \times \mathrm{X}$ & 0.99847 & $3.8 \times 10^{-7}$ & $0.00207-0.1035$ & 0.00207 \\
$\mathrm{RGox}$ & $\mathrm{H}=2.0 \times 10^{-9}+5.7 \times 10^{-8} \times \mathrm{C}$ & 0.99812 & $5.7 \times 10^{-8}$ & $0.001035-1.035$ & 0.001035 \\
$\mathrm{Ni}(\mathrm{II}) \mathrm{Pc} / \mathrm{RG} / \mathrm{RGox}$ & $\mathrm{H}=-6.8 \times 10^{-10}+1.5 \times 10^{-7} \times \mathrm{xC}$ & 0.99871 & $1.5 \times 10^{-7}$ & $0.001035-1.035$ & 0.001035 \\
\hline
\end{tabular}

${ }^{*} \mathrm{H}$ is the peak height $(\mathrm{A}) ; \mathrm{C}$ is the concentration $\left(\mu \mathrm{g} \mathrm{L}^{-1}\right)$

\section{Real samples}

Different types of waters (wasterwater, surface water, drinking water from spring, groundwater) were used for analytical determination of $\mathrm{Pb}^{2+}$ ions. Buffered water samples $(1: 1, \mathrm{v} / \mathrm{v})$ were screened using the proposed sensors before and after the addition of certain amounts of $\mathrm{Pb}^{2+}$ ions. The results obtained using anodic stripping voltammetry different linear concentration domain (0.00207$0.1035 \mu \mathrm{g} \mathrm{L}^{-1}$ ), in comparison with the modified electrodes based on reduced graphene oxide. However, the lowest limit of quantification was obtained for the reduced graphene oxide electrodes modified with Fe(II)Pc and Ni(II)Pc (0.001035 $\left.\mu \mathrm{g} \mathrm{L}{ }^{-1}\right)$.

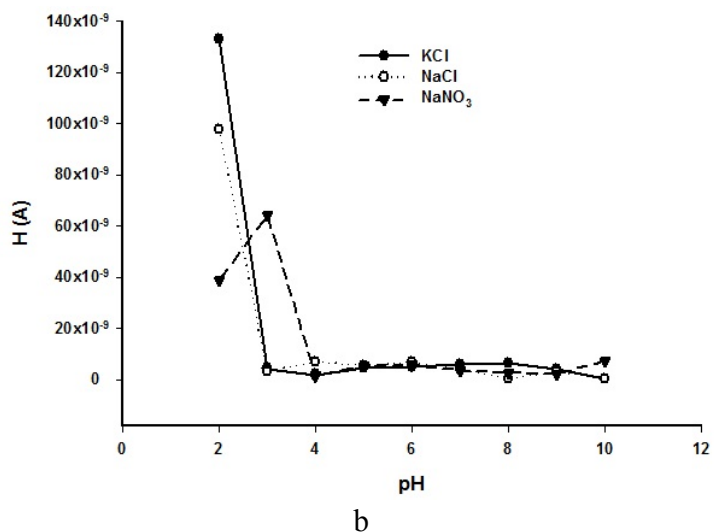

b 

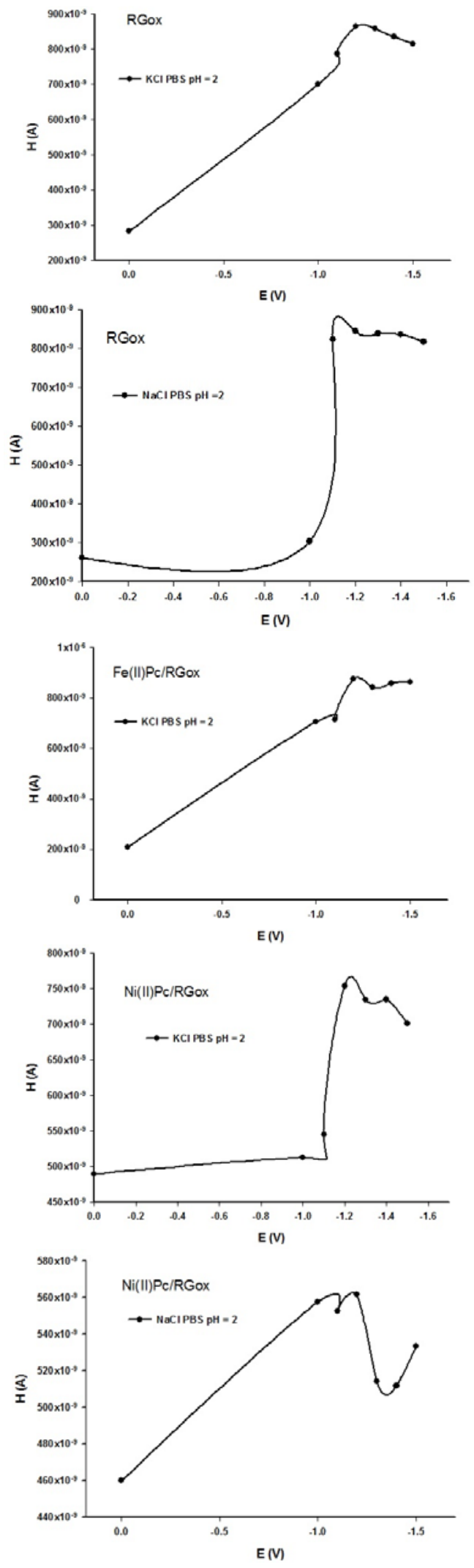

a
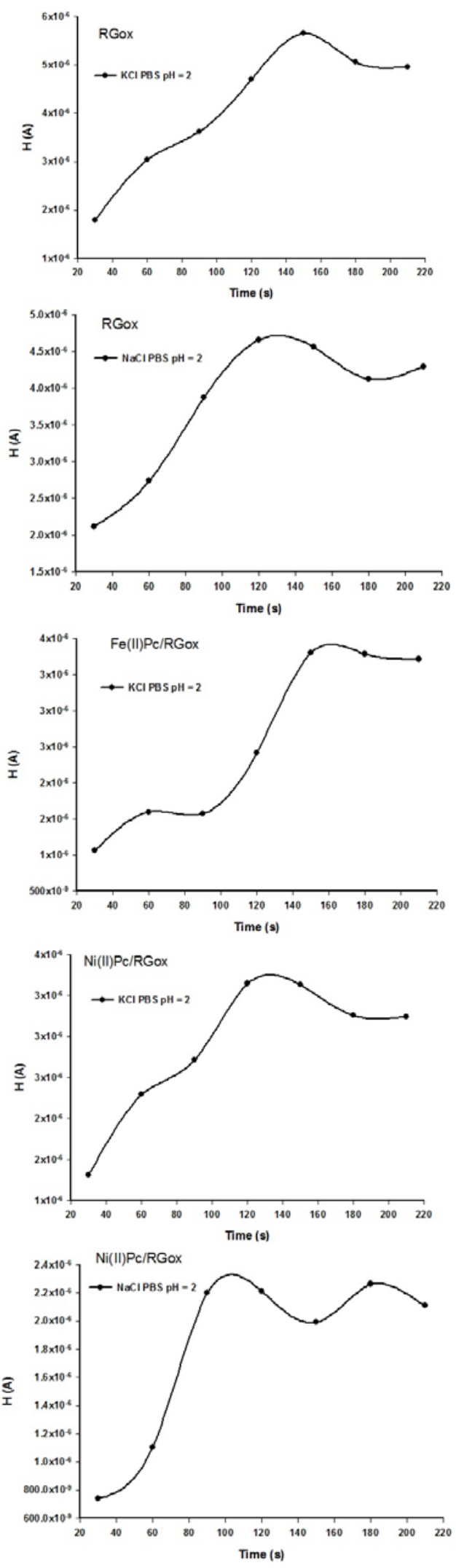

Fig. 2 - Influence of various parameters: a) deposition potential, b) deposition time for RGox with $0.1 \mathrm{~mol} \mathrm{~L}^{-1} \mathrm{KCl}, \mathrm{PBS} \mathrm{pH}=2$ as supporting electrolyte, RGox with $0.1 \mathrm{~mol} \mathrm{~L}^{-1} \mathrm{NaCl}$, PBS $\mathrm{pH}=2$ as supporting electrolyte, $\mathrm{Fe}(\mathrm{II}) \mathrm{Pc} / \mathrm{RGox}$ with $0.1 \mathrm{~mol} \mathrm{~L}^{-1} \mathrm{KCl}$, $\mathrm{PBS} \mathrm{pH}=2$ as supporting electrolyte, $\mathrm{Ni}(\mathrm{II}) \mathrm{Pc} / \mathrm{RGox}$ with $0.1 \mathrm{~mol} \mathrm{~L}^{-1} \mathrm{KCl}, \mathrm{PBS} \mathrm{pH}=2$ as supporting electrolyte, $\mathrm{Ni}(\mathrm{II}) \mathrm{Pc} / \mathrm{RGox}$ with $0.1 \mathrm{~mol} \mathrm{~L}^{-1} \mathrm{NaCl}$, PBS $\mathrm{pH}=2$ as supporting electrolyte, for a concentration of $\mathrm{Pb}^{2+}$ solution of $10^{-6} \mathrm{~mol} \mathrm{~L}^{-1}\left(207 \mu \mathrm{g} \mathrm{L}^{-1}\right)$ where $\mathrm{H}$ is the peak height $(\mathrm{A})$. 

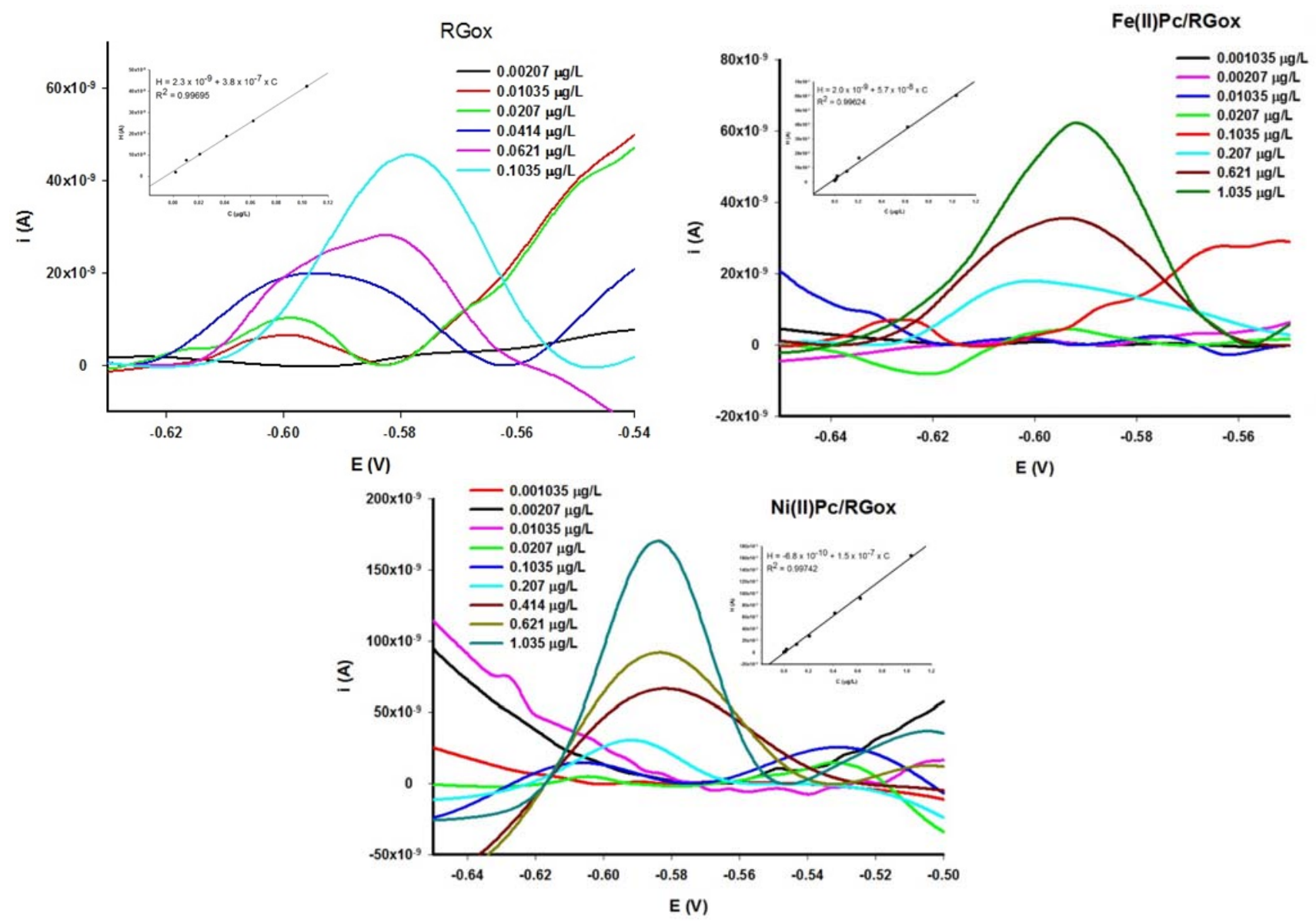

Fig. 3 - The anodic stripping voltamograms for the $\mathrm{Pb}^{2+}$ ions at different concentration; insert: the peak current vs. the concentration of $\mathrm{Pb}^{2+}$ ions.

Table 2

Sample results $\left(\mu \mathrm{g} \mathrm{L}^{-1}\right)$ from different types of water samples for $\mathrm{Pb}^{2+}$

\begin{tabular}{|c|c|c|c|c|}
\hline Sample/ Method & Sensors & RGox & Fe(II)Pc/RGox & Ni(II)Pc/RGox \\
\hline $\begin{array}{c}\text { Sample } 1 \\
\text { wastewater }\end{array}$ & $\begin{array}{c}\mathrm{ASV}^{* *} \\
\text { ICP-OES*** }\end{array}$ & $\begin{array}{c}5.47 \pm 0.15 \\
5.5\end{array}$ & $\begin{array}{c}5.44 \pm 0.19 \\
5.5\end{array}$ & $\begin{array}{c}5.47 \pm 0.15 \\
5.5\end{array}$ \\
\hline $\begin{array}{c}\text { Sample } 2 \\
\text { surface water }\end{array}$ & $\begin{array}{c}\mathrm{ASV}^{* *} \\
\text { ICP-OES*** }\end{array}$ & $\begin{array}{c}1.37 \pm 0.06 \\
1.40\end{array}$ & $\begin{array}{c}1.39 \pm 0.08 \\
1.40\end{array}$ & $\begin{array}{c}1.37 \pm 0.05 \\
1.40\end{array}$ \\
\hline $\begin{array}{c}\text { Sample } 3 \\
\text { drinking water from } \\
\text { spring water } \\
\end{array}$ & $\begin{array}{c}\mathrm{ASV}^{* *} \\
\mathrm{ICP}-\mathrm{OES} * * *\end{array}$ & $\begin{array}{c}1.01 \pm 0.04 \\
1.10\end{array}$ & $\begin{array}{c}1.08 \pm 0.02 \\
1.10\end{array}$ & $\begin{array}{c}0.88 \pm 0.05 \\
1.10\end{array}$ \\
\hline $\begin{array}{c}\text { Sample } 4 \\
\text { groundwater }\end{array}$ & $\begin{array}{c}\mathrm{ASV}^{* *} \\
\mathrm{ICP}-\mathrm{OES} * * *\end{array}$ & $\begin{array}{c}0.59 \pm 0.01 \\
0.6\end{array}$ & $\begin{array}{l}0.57 \pm 0.01 \\
0.6\end{array}$ & $\begin{array}{c}0.59 \pm 0.02 \\
0.6\end{array}$ \\
\hline
\end{tabular}

* Relative standard deviation for 5 measurements $(n=5)$

** ASV = anodic stripping voltammetry

***ICP-OES = Inductively coupled plasma atomic emission spectroscopy.

\section{CONCLUSION}

Several sensors based on reduced graphene oxide modified with $\mathrm{Fe}(\mathrm{II}) \mathrm{Pc}$ or $\mathrm{Ni}(\mathrm{II}) \mathrm{Pc}$ were proposed for the determination of $\mathrm{Pb}^{2+}$ ions. It can be seen that all sensors have the same parameters $\left(0.1 \mathrm{~mol} \mathrm{~L}^{-1} \mathrm{KCl}\right.$, PBS $\left.\mathrm{pH}=2\right)$. The highest linear domain for the sensors was recorded for the modified electrodes. All sensors have good results for the determination of $\mathrm{Pb}^{2+}$ ions in different types of water.

Acknowledgements. The authors gratefully acknowledge the Roumanian National Authority for Scientific Research, 
UEFISCDI for financial support, under grants PN-III-P2-2.1PED-2016-0181, PN-III-P4-ID-PCE-2016-0050 and the National Research and Development Institute for Industrial Ecology - INCD-ECOIND Bucharest for standard ISO-certified samples.

\section{REFERENCES}

1. T. Heberer, M. Lahrssen-Wiederholt, H. Schafft, K. Abraham, H. Pzyrembel, K.J. Henning, M. Schauzu, J. Braeunig, M. Goetz, L. Niemanni, U. Gundert-Remy, A. Luch, B. Appel, U. Banasiak, G. Fleur Bol, A. Lampen, R. Wittkowski and A. Hensel, Toxicol. Lett., 2007, 175, 118. (Doi: 10.1016/j.toxlet.2007.10.002).

2. P. Coppens, M. F. da Silva and S. Pettman, Toxicology, 2006, 221, 59. (DOI: 10.1016/j.tox.2005.12.022.)

3. T. Wenzl, R. Simon, E. Anklam and J. Kleiner, Trends. Analyt. Chem., 2006, 25, 716. (DOI: 10.1016/ j.trac.2006.05.010).

4. K. Grob, M. Biedermann, E. Scherbaum, M. Roth and K. Rieger, CRC. CR. Rev. Food Sci., 2006, 46, 529. (DOI: 10.1080/10408390500295490).

5. W. L. Bryden, Asia Pac. J. Clin. Nutr., 2007, 16, 95.

6. J. Fink-Gremmels, Vet. Quart., 1999, 21, 115. (DOI: 10.1080/01652176.1999.9695005).

7. M. E. Zain, J. Saudi. Chem. Soc., 2011, 15, 129. (DOI: 10.1016/j.jscs.2010.06.006).
8. M. Torrice, Chem. Eng. News., 2016, 94, 26.

9. T. H. Tulchinsky and E. A. Varavikova, "The New Public Health", Third Edition, 2014, p. 471. (DOI: 10.1016/B978-0-12-415766-8.00009-4).

10. World Health Organization International Agency for Research on Cancer, IARC Monographs on the Evaluation of Carcinogenic Risks to Humans, Inorganic and Organic Lead Compounds, Lyon, France, 2006, p. 87.

11. M. Dikilitas, S. Karakas and P. Ahmad, "Plant Metal Interaction Emerging Remediation Techniques", 2016, p. 41. (DOI: 10.1016/B978-0-12-803158-2.00003-5).

12. R. L. Canfield and T. A. Jusko, "Reference Module in Neuroscience and Biobehavioral Psychology Encyclopedia of Infant and Early Childhood Development", 2008, p. 200. (DOI: 10.1016/B978-012370877-9.00091-8).

13. K. Weizsaecker, Primary Care Update for $O B / G Y N S$, 2003, 10, 304. (DOI: 10.1016/S1068-607X(03)00074-X).

14. A.-M. Georgescu, F. Nardou, V. Zichil and I. Denisa Nistor, Appl. Clay. Sci., 2018, 152, 44. (DOI: 10.1016/j.clay.2017.10.031).

15. A. K. Juric, M. Batal, W. David, D. Sharp, H. Schwartz, A. Ing, K. Fediuk, A. Black, C. Tikhonov, H. M. Chan and L. Chan, J. Hazard. Mater., 2018, 344, 55. (DOI: 10.1016/j.jhazmat.2017.09.035).

16. U. S. Environmental Protection Agency, Lead and copper rule revisions white paper, 2016.

17. E. Süren, S. Yilmaz, M. Türkoglu and S. Kaya, Environ. Monit. Assess., 2007, 125, 91. (DOI: 10.1007/s10661006-9242-5). 